\title{
MOLECULAR EPIDEMIOLOGICAL STUDIES ON TRYPANOSOMA EVANSI TYPE A AND TYPE B IN CAMELS (CAMELUS DROMEDARIES) FROM FIVE DIFFERENT REGIONS OF SAUDI ARABIA USING THE ITS1 RDNA AND ROTAT 1.2 VSG GENE \\ By
}

\author{
ABDULLAH D. ALANAZI"1, R. PUSCHENDORF ${ }^{2}$, MOHAMED S. ALYOUSIF ${ }^{3}$, \\ MOHAMED S. AL-KHALIFA ${ }^{3}$, SAMIR A. ALHARBII ${ }^{1}$, ZAFER S. AL SHEHRI ${ }^{1}$, \\ ASHRAF E. SAID ${ }^{1,4}$, IBRAHIM O. ALANAZI ${ }^{5}$ and HAMDAN I. AL-MOHAMMED ${ }^{6}$ \\ Department of Biological Science ${ }^{1}$, Faculty of Science and Humanities, Shaqra \\ University, P.O. Box 1040, Ad-Dawadimi 11911, School of Biological Sciences ${ }^{2}$, \\ Plymouth University, Drake Circus, Plymouth, PL4 8AA, UK; email: robert. puschen- \\ dorf@plymouth.ac.uk.; Department of Zoology, College of Science ${ }^{3}$, King Saud \\ University, P.O. Box 2455, Riyadh 11451, email: myousif@ksu.edu.sa.; Department \\ of Zoology 4 , Faculty of Science, Damietta University, New Damietta, Damietta, Egypt. \\ E-mail: Ashraf@su.edu.sa.; The National Centre for Genomic Technology ${ }^{5}$, King Ab- \\ dulaziz City for Science and technology, P.O. Box 6086, Riyadh 11442,. email: iale- \\ nazi@kacst.edu.sa.; Department of Parasitology ${ }^{6}$, Faculty of Medicine, King Faisal \\ University P.O. Box 400, AlAhsa 31982, Saudi Arabia ${ }^{1,3,5,6}$, email: \\ hamdan@kfu.edu.sa. ('Correspondence: Tel.: +966559509323; Fax: \\ +966116423593: email:aalanazi@su.edu.sa.)
}

\begin{abstract}
Trypanosoma evansi is the most widespread of the pathogenic salivarian trypanosomes and cause a serious disease called (surra) that is affect the domestic animals such camels and horses in Tropical and subtropical countries and often leads to reduced productivity and economic losses. Therefore, the objectives of the present study were to determine the prevalence rates of trypanosomiasis using polymerase chain reaction (PCR) among camels from five different regions of Saudi Arabia and to sequence and characterized the T. evansi from these animals. In the current study, 832 camel blood samples collected from five different regions of Saudi Arabia for detecting T. evansi. A generic ITS1-PCR and RoTat 1.2 VSG gene were applied in this study to analyze camels' blood samples. Molecular analysis was performed using ITS1-PCR which showed that the highest prevalence of trypanosomes was observed in Al-Qaseem province $(50.1 \%)$ followed Riyadh province $(49 \%)$, whereas in Hail and the Northern Borders, there were fewer infections with trypanosomes $(28.4 \% \& 17.6 \%)$, respectively. PCR amplification was carried out targeting RoTat 1.2 VSG gene on TS1-positive samples and some of them were negative for RoTat1.2. The test negative in RoTat 1.2 PCR but ITS1 PCR positive could suggest $T$. evansi type B. Presence of $T$. evansi type B is interest to the international community, as this has a message to redesign the existing molecular and serological diagnostic markers. However, to our knowledge this the first study demonstrating T. evansi type B out of Africa.

Keywords: Trypanosoma evansi, Camels, ITS1 rDNA, RoTat 1.2, PCR, Saudi Arabia.
\end{abstract}

\section{Introduction}

Trypanosoma evansi is a protozoan parasite of both intra and extra vascular fluids of mammals causing the disease surra throughout tropical and subtropical regions of the world (Luckins, 1988). It has a large diversity of mammalian hosts. It is transmitted mechanically by hematophagous flies (Tabanus, Chrysops, Atylotus, Lyperosia, Haematopota and Stomoxys) causing production losses, anemia, weight loss, abortion and is fatal in a range of domestic and wild species (Luckins and Dwinger, 2004; Desquesnes et $a l, 2013)$. However, the disease is still a serious problem in camel husbandry that causes significant economic losses in many camel farms worldwide causing reduction in meat and milk (Derakhshanfar et al, 2010). Nevertheless, camels are particularly suscepptible to surra (OIE, 2010). Several parasito- 
logical tests were applied for diagnosis of Surra such as haematological and microscopic examinations (Ravindran et al, 2008; Shyam et al, 2013), or serological tests such as the card agglutination test (CATT/T. evansi) (Songa and Hamers, 1988; Njiru, et al, 2004), enzyme-linked immunosorbent assay (ELISA) (Olaho-Mukani et al, 1996; Ngaira et al, 2003; Aslam et al, 2010), the latex agglutination test (Verloo et al, 1998), the immune trypanolysis (TL) assay (Van Meirvenne et al, 1995), and immunofluorescence antibody test (IFAT) (Katende et al, 1987). However, these tests cannot differentiate between past and recent infections and lack sensitivity and specificity.

Polymerase chain reaction (PCR) assays appear to be a promising technique for the diagnosis of trypanosomal infection based on the detection of trypanosomal DNA in the blood samples due to its sensitivity and specificity in detecting all the stages of an infection (Clausen et al, 1998). Various target sequences such as ribosomal DNA, internal transcribed spacer region (ITS), kinetoplast DNA and VSG genes are reliable targets for detection of $T$. evansi (Urakawa et al, 2001; Verloo et al, 2001; Cox et al, 2005; Njiru et al, 2005; Sengupta et al, 2010; Salim et al, 2011; Birhanu et al, 2015; Sumbria et al, 2015; El Wathig et al, 2016; Tehseen et al, 2017).

In Saudi Arabia, the camel populations are estimated at nearly $1,356,7290$ heads. Besides, thousands of live camels imported annually from neighboring countries such as Sudan, Somalia, Djibouti and Arabian Gulf countries (General Authority for Statistic, 2015). They are mainly used as a source of meat, milk, skin, leathers and load carrying, which is an important role in transportation in the desert and rural areas. However, there are lack of information on trypanosomiasis infections in Saudi animals particularly at the molecular levels and the most of the previous studies conducted in camels from Saudi Arabia were epidemiological, serological, biochemical and haematological stud- ies (Kasim, 1984; Hussein et al, 1991; Omer et al, 1998; Al-Khalifa et al, 2009; Al-Afaleq et al, 2015; El Wathig et al, 2016).

The objectives of the present study were to determine the prevalence rates of trypanosomiasis using PCR among camels from five different regions of Saudi Arabia and to sequence and characterized the T. evansi from these animals.

\section{Materials and Methods}

Study areas: The investigation was conducted over a year from April 2016 to June 2017 in five different regions of Saudi Arabia; in the Central Region (Riyadh), the Eastern Province, Al-Qaseem Province, Hail and Northern Borders (Fig. 1).

Sampling and blood collection: 832 camels (271 males \& 561 females) with ages $0 \leq 4$ year to $>4$ years old) were examined for trypanosomiasis. All animals were apparently clinically healthy at the time of blood collections. Blood samples collected from each animal $(5-10 \mathrm{ml})$ from jugular vein into vacutainer EDTA tubes (BD Vacutainer ${ }^{\circledR}$ Tube, Gribbles Pathology, VIC, Australia) and transported to Parasitological Laboratory, Department of Biological Sciences, Faculty of Science and Humanities, Shaqra University for DNA extraction.

DNA extraction: Total genomic DNA (gDNA) was isolated using the DNeasy Blood and Tissue kit (Qiagen, Hilden, Germany) and eluted in $50 \mu 1$ or $100 \mu$ l of elution buffer as per the manufacturer's instruction. An aliquot between $50 \mu 1-100 \mu 1$ of gDNA from each of the samples was stored at -80 ${ }^{\circ} \mathrm{C}$ prior to being sent to the Molecular Laboratory, School of Biological and Marine Sciences, Plymouth University for PCR analysis. At the Molecular Labora-tory, gDNA was stored at $-20^{\circ} \mathrm{C}$ for up to a month prior to molecular diagnostics.

Trypanosoma evansi PCR:A Two-step PCR protocols were used to analyze $T$. $e v$ ansi in DNA samples. In the first step, DNA samples were used to amplify the 250-270bp region of ITS gene using forward primer ITS1 CF (5'-CCGGAAGTTCACCG 
ATATTG-3') and reverse primer ITS1 BR (5'-TGCTGCGTTCTTCAACGAA-3'), the primers are specific for parasites belonging to the genus Trypanosoma and amplifying a $250 \mathrm{bp}, 400 \mathrm{bp}, 480 \mathrm{bp} \& 700 \mathrm{bp}$ for region of ITS1 of T. vivax, T. simiae, T. brucei subspecies and $T$. congolense savannah, respecttively (Njiru et al, 2005). Then positive ITS1 $T$. evansi isolates were further subjected to PCR test specific for T. evansi, in which a primer set that amplifies $151 \mathrm{bp}$ of the T. evansi RoTat 1.2 VSG gene fragment was used (Konnai et al, 2009), this was TeRoTat920F (5'-CTGAAGAGGTTGGAAATG GAGAAG-3') and TeRoTat1070R (5'-GT TTCGGTGGTTCTGTTGTTGTTA-3'), and then all PCR reactions were performed in a final volume of $50 \mu \mathrm{l}$ containing $25 \mu \mathrm{l}$ of Dream Taq DNA polymerase Master Mix $2 \mathrm{X}$ (Thermo Scientific ${ }^{\mathrm{TM}}$, UK), $0.4 \mu \mathrm{M}$ $(1 \mu \mathrm{L})$ of each primer and $2 \mu \mathrm{L}$ of DNA template. The reaction was brought to $50 \mu \mathrm{L}$ total volume with PCR grade water (Invitrogen, UK). Positive and negative controls were included in all assays. Thermal cycling conditions for Trypanosoma species were consisted of an initial $2 \mathrm{~min}$ incubation at $95^{\circ} \mathrm{C}$, followed by 40 cycles of denaturation at $95^{\circ} \mathrm{C}$ for $\left.30 \mathrm{sec}\right)$, primer annealing $\left(58^{\circ} \mathrm{C}\right.$ for $30 \mathrm{sec}$ and extension at $72^{\circ} \mathrm{C}$ for $1 \mathrm{~min}$. and a final extension step at $72^{\circ} \mathrm{C}$ for $5 \mathrm{~min}$ and the samples held at $4{ }^{\circ} \mathrm{C}$. Aliquots of $10 \mu \mathrm{L}$ PCR product was electrophoresed on a $1.5 \%$ agarose gel containing $10 \mu \mathrm{L} / \mathrm{mL}$ Syber safe (Thermo Scientific TM, UK) in Trisacetate-EDTA buffer at $100 \mathrm{~V}$ for $45 \mathrm{~min}$ and photographed under UV imaging system (ImagQunat Laz4000, GE Healthcare Life Science, UK). Size of each product was estimated by comparison with a Gene Ruler 100bp DNA Ladder Marker (Thermo Scientific $^{\mathrm{TM}}, \mathrm{UK}$ ).

Sequencing and phylogenetic trees analysis: To determine the T. evansi, positive samples were sent to Macrogen Europe (Netherlands) for sequencing ITS1 region using forward ITS1 CF and reverse ITS1 BR primers and the results were compared with the sequences available at GenBank data-base using BLAST (http://blast.ncbi.nlm. nih.gov/). Phylogenetic analysis was constructed by comparing identified sequence in this study with the related sequences from GeneBank using the neighbor-joining method with the distance algorithms available in the Molecular Evolutionary Genetics Analysis package (MEGA7).

Statistical analysis: Statistical analyses were performed with the statistics package SPSS (Version 17.0; IBM, New York, USA). Animals were divided into two age groups, animals up to 4 years (young) and animals more than 4 years old (mature). The association between the prevalence of $T$. $\mathrm{ev}$ ansi and risk factors such as location, sex and age was determined using the chi-square test of significant $P$ value $(p<0.05)$.

\section{Results}

Based on ITS1-PCR results, the prevalence of trypanosomiasis evansi in the camels was $42.3 \%$ (Fig. 2). The PCR amplification was carried out targeting RoTat 1.2 VSG gene on TS1-positive samples and some of them were negative for RoTat 1.2 (Fig. 3). The test negative in RoTat 1.2 PCR but ITS1 PCR positive could suggest T. evansi type $\mathrm{B}$.

The phylogenetic data and blast results of ITS 1 showed that $T$. evansi is closely related to Trypanosome evansi isolate SANSTEFANO-HS, accession number MG564285 isolated from tick infesting Canis lupus familiaris in Egypt (Fig. 4). The phylogenetic tree inferred from the ITS1 nucleotide sequences $(490 \mathrm{bp}$ ) was unable to show interand intraspecific genetic diversity of the parasites. In the current study, the sequences of new isolates of ITS1 from positive Trypanosoma evansi isolated from Saudi camels deposited in the GenBank (National Center for Biotechnology Information, NCBI) database under accession numbers $\underline{\mathrm{MH} 087230}$.

The highest prevalence of trypanosomosis was in Al-Qaseem Province $(50.1 \%$ ) followed by Riyadh Province (49\%), whereas in Hail and the Northern Borders, there were 
fewer infections $(28.4 \% \& 17.6 \%)$, respectively (Tab. 1). The results show that female camels to be the most infected with $T$. evansi (47\%), while male camels infected with $T$. evansi $(32.5 \%)$. Most T. evansi infections were recorded in camels over four years old

Table 1: Number and prevalence of Trypanosomiasis in camels.

\begin{tabular}{|c|c|c|c|c|c|}
\hline Factor & & No of Camels & Trypanosomiasis & Trypanosomiasis & P-value \\
\hline & & examined & Positive & Negative & \\
\hline Sex & Male & 271 & $88(32.5 \%)$ & $183(67.5 \%)$ & 0.333 \\
\hline & Female & 561 & $264(47 \%)$ & $297(53 \%)$ & \\
\hline & Total & 832 & & & \\
\hline Age & $<4$ years & 305 & $93(30.5 \%)$ & $212(69.5 \%)$ & 0.333 \\
\hline & $>4$ Years & 527 & $259(49.1 \%)$ & $268(50.9 \%)$ & \\
\hline \multicolumn{6}{|c|}{ P >0.05 = Non significant } \\
\hline
\end{tabular}

Table 2: Effect of sex and age factors on prevalence of trypanosomiasis in camels.

\begin{tabular}{|l|c|c|c|c|}
\hline Location & No of Camels & Trypanosomiasis & Trypanosomiasis & P-value \\
\hline & examined & Positive & Negative & 0.00000 \\
\hline Riyadh & 237 & $116(49 \%)$ & $121(51 \%)$ & \\
\hline Eastern province & 221 & $106(48 \%)$ & $115(52 \%)$ & \\
\hline Al-Qaseem & 156 & $79(50.1 \%)$ & $75(49.4 \%)$ & \\
\hline Hail & 116 & $33(28.4 \%)$ & $83(71.6 \%)$ & \\
\hline Northern Boarders & 102 & $18(17.6 \%)$ & $84(82.4 \%)$ & \\
\hline \multicolumn{6}{|c|}{ Total } & 832 & $352(42.3 \%)$ & $480(57.7 \%)$ & \\
\hline \multicolumn{5}{|c|}{ P $<0.05$ significant } \\
\hline
\end{tabular}

\section{Discussion}

In an attempt to explore the status of trypanosomosis in Saudi Arabia and the $T$. evansi that causes it, we carried out this study and applied the generic ITS1-PCR test to analyze 832 samples collected from camels in five regions of Saudi Arabia. The PCR test is increasingly used in surveys to study trypanosomosis in different countries (Njiru et al, 2005; Ravindran et al, 2008; Bhutto et al, 2010; Salim et al, 2011; Elhaig et al, 2013; Hussain et al, 2016; Tehseen et al, 2017). However, this method has drawbacks on field, DNA samples have a problem of specificity not sensitivity of the ITS $1 \mathrm{CF}$ and BR primers, which range between 10pg (100 trypanosomes) for Trypanozoon, T. vivax and $T$. congolense clades to 100pg (1000 trypanosomes) for $T$. simiae and $T$. godfreyi (Njiru et al, 2005). It also cannot differentiate between the different species of $T$. brucei subgroup at its sub-species level. Based in ITS1 region, Njiru et al. (2005) and Cox et al. (2005) documented specific PCR product length corresponding to each Trypanosoma
(49.1\%), while infections in young camels constituted $(30.5 \%)$. The results show no significant effects of age and sex on the prevalence of $T$. evansi in camels $(p=0.333$ and 0.333 ), respectively. 
the Sudan to Saudi Arabia.

Historically, camel trypanosomiasis have spread to Saudi Arabia from the neighboring countries since it has been reported in all the countries bordering Saudi Arabia (Boid et $a l, 1985)$. However, the present study is the first molecular survey nationwide in Saudi Arabia that showed that the prevalence rate of T. evansi detected by PCR was $42.3 \%$ in camels. This rate is higher than those reported in other studies in different locations in Saudi Arabia. For example, El Wathig et al. (2016) examined 195 camels from Al-Jouf Province, Northern part of Saudi Arabia, and they found that $25 \%$ of camels were infected with $T$. evansi. Other studies on the T. evansi infection in camels were microscopy or serological studies. For example, Kaism (1984) reported an overall incidence of $2 \%$ of camel trypanosomiasis in Saudi Arabia by using the direct stained thin blood smear examination technique. However, a higher incidence rate of $13.2 \%$ was detected (Hussain et al, 1991). Omer et al. (1998) reported a prevalence of $5.5 \%$ among camels in Al-Qaseem region. Al-Khalifa et al. (2009) documented the incidence rate of $T$. evansi in camels from 0 to $40 \%$ in different regions in Saudi Arabia. In contrast, Afaleq et al., (2015) reported the prevalence of $T$. evansi infection among camels in different regions of Saudi Arabia was $0.8 \%$. Serologically, Omer et al. (1998) found that $19.7 \%$ of the sampled camels in Al-Qaseem region were positive for trypanosomes by the passive hemagglutination test and $13.8 \%$ by Ag-ELISA. But, El-Wathig and Faye (2013) and Afaleq et al. (2015) reported that the prevalence of $T . e v$ ansi, using CATT/T. evansi test was $43.8 \%$ and $39.4 \%$ respectively.

Studies in neighboring countries also recorded different results. For example, in Iraq, Al-Amery et al., (2017) recorded the prevalence of Trypanosoma spp. by blood smears as $31.87 \%$, Al-Rawashdeh et al. (2000) reported that Trypanosoma was $33 \%$ in Jordan. In Egypt, studies showed that Trypanosoma spp. prevalence was $4.5 \%-74.4 \%$
(Abdel-Rady 2006; Zayed et al, 2010; Elhaig et al, 2013; Barghash et al, 2014). On the other hand, Haridy et al. (2011) stated that the mortality rate was up to $20 \%$ and fatality rate might reach up to $100 \%$ in untreated camels and reported the first Egyptian human case which was successfully treated as indicated clinically, parasitologically and serologically. In Sudan, Trypanosoma spp prevalence rate and infection pattern were also performed with varied estimates of prevalence at $5.4 \%$ using parasitological examination and $1.3 \%$ with ELISA (Elamin et $a l, 1998)$. The overall prevalence by using molecular epidemiological tools ranged from 33.9 to $42.1 \%$, respectively (Salim et al, 2011). The differences might be attributed to the differences of the management and the environment in which these studies were performed, sampling size of tested animals or methods of PCR or microscopic and serological methods that used, animals natural immunity and local climatic conditions that had an effect on tabanid flies distribution (Al-Khalifa et al, 2008).

The present results showed that the pattern of prevalence of $T$. evansi in camels differed according to the different locations because of the variations of the environment conditions. The data agreed with others in Saudi Arabia (Al-Khalifa et al, 2009; El Wathig et $a l, 2016$ ) and other countries (Barghash et al, 2014; Tehseen et al, 2015). The environment conditions favor the distribution of biting flies vectors of $T$. evansi (Schillinger and Rottcher, 1986).

The current results showed no significant effect of sex where by female were more infected than males $(\mathrm{P}>0.333)$. These data agreed with studies from Nigeria (Joshua et al, 2008), Egypt (Barghash et al, 2014; ElNaga and Barghash, 2016), Pakistan (theseen et al, 2015). But, disagreed with Bogale et al. (2012); Hussain et al. (2016) and AlAmery et al. (2017) who reported that male camels was more infected than females in Ethiopia, Pakistan and Iraq, respectively. The higher prevalence in females in this 
study might be due to the fact all samples were from female camels $(67.4 \%)$. Another reason could be due to pregnancy. A pregnant female with weak immunity that led to reduce resistance compared to male camels (Bhutto et al, 2010).

In addition, the present results showed no significant effect of age on the rate of T. evansi infection $(\mathrm{P}>0.333)$ and that most $T$. evansi infections were present among animals with ages equal to or more than four years. These results agreed with previous studies (Diall et al, 1993; Bogale et al, 2012; Tehseen et al, 2015; Al-Amery et al, 2017). The high infection rate in adult camels could be attributed to several factors such as the movements and travel of camels where the fly burden is high, poor management, stress, drought, poor silage and preference by biting flies (Njiru et al, 2004; Bhutto et al, 2010; Tehseen et al, 2015).

\section{Conclusion}

The outcome data showed that PCR is a more specific, sensitive and reliable tool for the detection of $T$. evansi in camel blood samples than the other methods used previously in Saudi Arabia. This study showed that only $T$. evansi was detected in camels in Saudi Arabia and no other trypanosomes were noticed. Also, some samples tested negative by RoTat 1.2 VSG-PCR and positive by ITS1-PCR. Therefore, ITS1-PCR is recommended for general trypanosomiasis detection but no specific for T. evansi.

Competing interests: The authors declared that they neither had competing interests nor received fund

Authors' contributions: ADA and PR developed the study design. MS and MSA coordinated the study design and the related activities. ADA, IOA, SAA and ZSA carried out the field and laboratory investigations of all the experiments. AES and IOA, carried out the statistical analysis, PR and ADA analysis phylogenetic tress. ADA, HIA and PR prepared and revised the manuscript. All authors read and approved the final manuscript.

\section{Acknowledgements}

This study was kindly supported by Shaqra University, Deanship of Scientific Research and Plymouth University, UK. The authors would like to thank the Staff Members of Biological Science Department, Faculty of Science and Humanities, Shaqra University and the members of the Molecular laboratory, School of Biological Science, Plymouth University for kind technical support.

\section{References}

Abdel-Rady, A, 2006: Comparison of card agglutination test and parasitological methods for the diagnosis of camel trypanosomosis in Egypt. In Proceedings of the 2004 International Science Conference on Camels. Qassim, Saudi Arabia.

Al-Afaleq, AI, Elamin, EA, Fatani, A, Homeida, AGM, 2015: Epidemiological aspects of camel trypanosomosis in Saudi Arabia. J. Camel Pract. Res. 22:231-4.

Al-Amery, AM, Faraj, AA, Majeed, SA, 2017: Detection of haemoprotozoa in camle in ALNajaf province, Iraq Inter. J. Adv. Biol. Res. 7: 238-41.

Al-Khalifa, M, Hussein, H, Diab, F, Khalil, G, 2009: Blood parasites of livestock in certain regions in Saudi Arabia. Saudi J. Biol. Sci. 16: 63-7.

Al-Khalifa, M, Khalil, G, Hussein, H, Diab, F, 2008: A preliminary study on the effect of a concurrent infection with Eperythrozoon wenyonii on the development of Theileria annulata in calves. Saudi J. Biol. Sci.15:73-9.

Aslam, A, Chaudhary, ZI, Rehman, H, Ashraf, K, Ahmad, N, et al, 2010: Comparative evaluation of parasitological, serological and DNA amplification methods for diagnosis of natural trypanosomal infection in equines. Pakistan Vet. J. 42:371-6.

Barghash, SM, Abou El-Naga, TR, El-Sherbeny, EA, Darwish, AM, 2014: Prevalence of Trypanosoma evansi in Maghrabi Camels (Camelus dromedarius) inNorthern-West Coast, Egypt using molecular and parasitological method. Acta Parasitol. Glob. 5:125-32.

Bhutto, B, Gadahi, J, Shah, G, Dewani, P, Arijo, A, 2010: Field investigation on the prevalence of trypanosomiasis in camels in relation to sex, age, breed and herd size. Pakistan Vet. J.30, 175-7.

Birhanu, H, Fikru, MR, Said, W, Kidane, T, Gebrehiwot, A, et al, 2015: Epidemiology of 
Trypanosoma evansi and Trypanosoma vivax in domestic animals from selected districts of Tigray and Afar regions, Northern Ethiopia. Parasit.Vect. 8:212.

Birhanu, H, Gebrehiwot, T, Goddeeris, BM, Büscher, P, Van Reet, N, 2016: New Trypanosoma evansi type B isolates from Ethiopian dromedary camels. PLoS Negl. Trop. Dis. 10, e0004556.

Bogale, B, Kelemework, F, Chanie, M, 2012: Trypanosomosis in camel (Camelus dromedari$u s$ ) in Delo-Mena District, Bale Zone, Oromia Region, Southwest Ethiopia. Acta Parasitol. Glob. 3:12-5.

Boid, R, Jones T, Luckins, A, 1985: The camel in health and disease.3. Protozal diseases of camles. Brit. Vet. J. 141:87-105.

Clausen, PH, Wiemann, A, Patzelt, R, Kakaire, D, Poetzsch, C, et al,1998: Use of a PCR assay for the specific and sensitive detection of Trypanosoma spp. in naturally infected dairy cattle in peri-urban Kampala, Uganda. Ann. N Y Acad. Sci. 8:49-53.

Cox, A, Tilley, A, McOdimba, F, Fyfe, J, Eisler, M, et al, 2005: A PCR based assay for detection and differentiation of African trypanosome species in blood. Exp. Parasitol. 111:24-9.

Derakhshanfar, A, Mozaffari, A, Zadeh, AM, 2010: An outbreak of trypanosomiasis (Surra) in camels in the Southern Fars province of Iran: Clinical, hematological and pathological findings. Res. J. Parasitol. 5:23-6.

Desquesnes, M, Holzmuller, P, Lai, DH, Dargantes, A, Lun, ZR, et al, 2013: Trypanosoma evansi and surra: a review and perspectives on origin, history, distribution, taxonomy, morphology, hosts, and pathogenic effects. BioMed. Res. Int. 194176. doi: 10.1155/2013/194176.

Diall, O, Coumare, A, Diarra, B, Sanogo, Y, Conlibaly, Z, 1993: Epidemology of trypanosomiasis cused by $T$. evansi in camels male results of parasitological and clinical survey. Rev. Elev. Med. Pays Trop 46:455-61.

El-Naga, T, Barghash, S, 2016: Blood parasites in camels (Camelus dromedarius) in Northern west coast of Egypt. J. Bacteriol. Parasitol. 7:24.

El Wathig, M, Faye, B, Thevenon, S, Ravel, S, Bossard, G, 2016: Epidemiological surveys of cam-el trypanosomosis in Al-jouf, Saudi Arabia based on PCR and ELISA. Emirates J. Food Agric. 28: 212-6.
Elhaig, MM, Youssef, AI, El-Gayar, AK, 2013: Molecular and parasitological detection of Trypanosoma evansi in camels in Ismailia, Egypt. Vet. Parasitol. 198:214-8.

General Authority for Statistic, 2015: Detailed results of the Agriculture Census. Kingdom of Saudi Arabia, 421.

Haridy, FM, El-Metwally, MT, Khalil, HHM, Morsy, TA, 2011: Trypanosoma evansi in dromedary camel: With a case report of zoonosis in Greater Cairo, Egypt. J. Egypt. Soc. Parasitol. 41, 1:65-76.

Hussain, M, Saeed, MZ, Gulsher, R, Shaikh, M, Ali, A, et al, 2016: A report on the molecular detection and seasonal prevalence of Trypanosoma brucei in dromedary camels from Dera Ghazi Khan District in Southern Punjab (Pakistan). Trop. Biomed. 33:268-75.

Hussein, HS, Al-Asgah, NA, Al-Khalifa, MS, Diab, FM, 1991: The blood parasites of indigenous livestock in Saudi Arabia. Arab Gulf J. Sci. Res. 9:143-60.

Joshua, K, TurkaiI, AU, Egwu, GO, Usman, A, Saidu, MK, et al, 2008: Haemoparasites of camels (Camelus dromedarius) in Maiduguri, Nigeria. Anim. Res. Inter. 5:838-9.

Kasim, A, 1984: Detection of Trypanosoma evansi in the Arabian Camel. J. Coll. Sci., King Saud University 15:423-7.

Katende, J, Musoke, A, Nantulya, V, Goddeeris, B, 1987: A new method for fixation and preservation of trypanosomal antigens for use in the indirect immunofluorescence antibody test for diagnosis of bovine trypanosomiasis. Trop-ical medicine and parasitology: official organ of Deutsche Tropenmedizinische Gesellschaft and of Deutsche Gesellschaft fur Technische Zusammenarbeit (GTZ) 38:41-4.

Konnai, S, Mekata, H, Mingala, CN, Abes, N S, Gutierrez, CA, et al, 2009: Development and application of a quantitative real-time PCR for the diagnosis of Surra in water buffaloes. Infect. Genet. Evol. 9:449-52.

Luckins, A, 1988: Trypanosoma evansi in Asia. Parasitol. Today 4:137-42.

Luckins, AG, Dwinger, RH, 2004: Non-tsetsetransmitted animal Trypanosomiasis. In: Maudlin, I., Holmes, PH, Miles, MA. (Eds.), The Trypanosomiases. Cabi Publishing, Trowbidge.. Lun, ZR, Fang, Y, Wang, CJ, Brun, R, 1993: Trypanosomiasis of domestic animals in China. Parasitol. Today 9:41-5. 
Ngaira, J, Bett, B, Karanja, S, Njagi, E, 2003: Evaluation of antigen and antibody rapid detection tests for Trypanosoma evansi infection in camels in Kenya. Vet. Parasitol. 114:131-41.

Ngaira, JM, Njagi, ENM, Ngeranwa, JJN, Olembo, NK, 2004: PCR amplification of RoTat 1.2 VSG gene in Trypanosoma evansi isolates in Kenya. Vet. Parasitol. 115:20-4.

Njiru, Z, Constantine, C, Guya, S, Crowther, J, Kiragu, J, et al, 2005: The use of ITS1 rDNA PCR in detecting pathogenic African trypanosomes. Parasitol. Res. 95:186-92.

Njiru, Z, Constantine, C, Masiga, D, Reid, S, Thompson, R, et al, 2006: Characterization of Trypanosoma evansi type B. Infect. Genet. Evol. 6:292-300.

Njiru, Z, Constantine, C, Ndung'u, J, Robertson, I, Okaye, S, et al, 2004: Detection of Trypanoso-ma evansi in camels using PCR \& CATT/T. evansi tests in Kenya. Vet. Parasitol. 124:187-99.

OIE, 2010: Terrestrial Manual: Trypanosoma evansi Infection (Surra).World Organization for Animal Health (OIE). Paris, France 2.1.17:1-14.

Olaho-Mukani, W, Nyang'ao, J, Ouma, J, 1996: Use of Suratex for field diagnosis of patent and non-patent Trypanosoma evansi infections in camels. Bri. Vet. J. 152:109-11.

Omer, O, Magzoub, M, Haroun, E, Mahmoud, O, Hamid, Y, 1998: Diagnosis of Trypanosoma evansi in Saudi Arabian camels (Camelus dromedarius) by the passive haemagglutination test and Ag-ELISA. Zoo. Publ. Hlth. 45:627-33.

Ravindran, R, Rao, JR, Mishra, AK, Pathak, KML, Babu, N, et al, 2008: Trypanosoma evansi in camels, donkeys and dogs in India: comparison of PCR and light microscopy for detection-short communication. Vet. Arhiv. 78:8994.

Salim, B, Bakheit, MA, Kamau, J, Nakamura, I, Sugimoto, C, 2011: Molecular epidemiology of camel trypanosomiasis based on ITS1 rDNA and RoTat 1.2 VSG gene in the Sudan. Parasit. Vect. 4:31.

Schillinger, D, Rottcher, D, 1986: Traitement de l'infection cameline due a Trypanosoma evansi (surra). Rev. mond. de Zootech. 3:26-32.

Sengupta, P, Balumahendiran, M, Suryanaryana, V, Raghavendra, A, Shome, B, et al, 2010: PCR-based diagnosis of surra-targeting
VSG gene: Experimental studies in small laboratory rodents and buffalo. Vet. Parasitol. 171: 22-31.

Shyam, K, Gupta, S, Singh, A, Chaudhary, S, Gupta, JP, 2013: Detection of Trypanosoma evansi in whole blood of domestic animals by DNA amplification method. Indian J. Anim. Res. 47:456-9.

Sumbria, D, Singla, L, Sharma, A, Bal, M, Kumar, S, 2015: Multiplex PCR for detection of Trypanosoma evansi and Theileria equi in equids of Punjab, India. Vet.arasitol. 211:293-9.

Tehseen, S, Jahan, N, Desquesnes, M, Shahzad, I, Qamar, MF, 2017: Field investigation of Trypanosoma evansi and comparative analysis of diagnostic tests in horses from Bahawalpur, Pakistan. Turk. J. Vet. Anim. Sci. 41:288-93.

Tehseen, S, Jahan, N, Qamar, MF, Desquesnes, M, Shahzad, MI, et al, 2015: Parasitological, serological and molecular survey of Trypanosoma evansi infection in dromedary camels from Cholistan Desert, Pakistan. Parasit. Vect. 8:415-9.

Urakawa, T, Verloo, D, Moens, L, Büscher, P, Majiwa, PA, 2001: Trypanosoma evansi: cloning and expression in Spodoptera fugiperda insect cells of the diagnostic antigen RoTat1. 2. Exp. Parasitol. 99:181-9.

Van Meirvenne, N, Magnus, E, Büscher, P, 1995: Evaluation of variant specific trypanolysis tests for serodiagnosis of human infections with Trypanosoma brucei gambiense. Acta Trop. 60: 189-99.

Verloo, D, Magnus, E, Büscher, P, 2001: General expression of RoTat 1.2 variable antigen type in Trypanosoma evansi isolates from different origin. Vet. Parasitol. 97:185-91.

Verloo, D, Tibayrenc, R, Magnus, E, Büscher, P, Meirvenne, NV, 1998: Performance of ecological tests for Trypanosoma evansi infections in camels from Niger. J. Protozool. 8:190-3.

Zayed, AA, Habeeb, SM, Allam, NAT, Ashry, HMZ, Mohamed, AHM, et al, 2010: A critical comparative study of parasitological and serological differential diagnostic methods of Trypanosoma evansi infections in some farm animals in Egypt. Am.-Eurasian J. Agr. Environ. Sci. 8:633-42. 


\section{Explanation of figures}

Fig. 1: Map showing the location of the study areas in Saudi Arabia.

Fig. 2: Agarose gel electrophoresis (1.7\%) of amplified DNA from collected samples using ITS1 CF / ITS1 BR. M, 100 bp molecular size marker (Generuler); Lane N, negative PCR control (water); T. T. evansi-positive control DNA; lanes 1-26 template DNA isolated from camels blood sample from different locations.

Fig. 3: Agarose gel electrophoresis (1.7\%) of amplified RoTat 1.2 VSG gene of T. evansi using specific primers TeRoTat920F and TeRoTat1070R. M, 100 bp molecular size marker (Generuler); Lane T.e, T. evansi-positive control DNA; N, negative PCR control (water); Samples (1-26) shown here from geographically different areas; Lane: 1 and 6 from Riyadh ; Lane; 7-13 from Eastern province; Lane: 14 and 18 from Al-Qaseem province; Lane: 19-23 from Hail; Lane: 24-26 from Northern Borders. Arrows indicate 151 bp amplicons specifically generated using TeRoTat920F and TeRoTat1070R primer set.

Fig. 4: Phylogenetic relationships of Saudi isolates of Trypanosoma parasites with other salivarian trypanosomes based on ITS 1 region of rRNA. GenBank accession numbers given in parentheses, Evolutionary history inferred by using Maximum Likelihood method based on Tamura-Nei model. Evolutionary analyses were conducted in MEGA7.
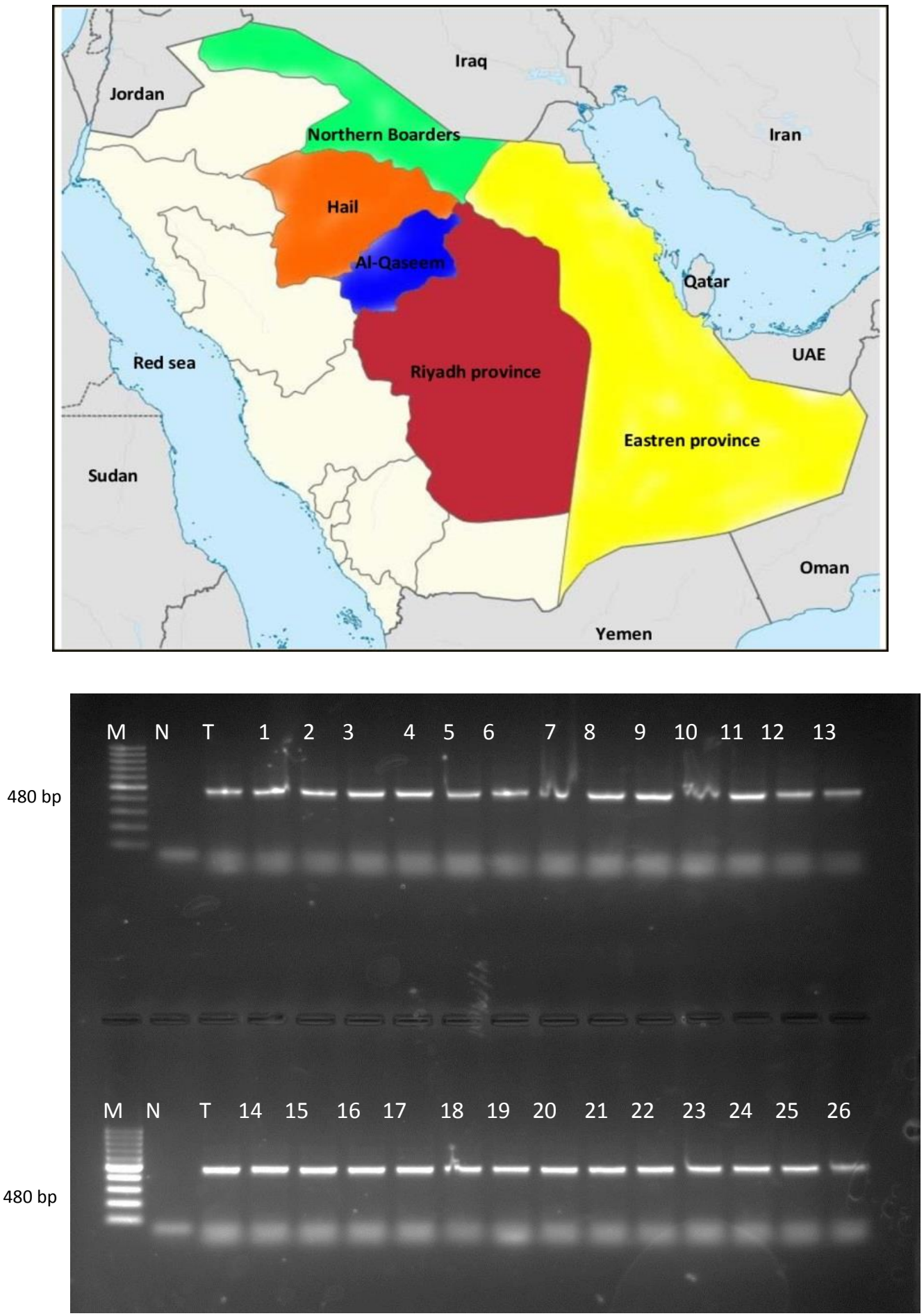

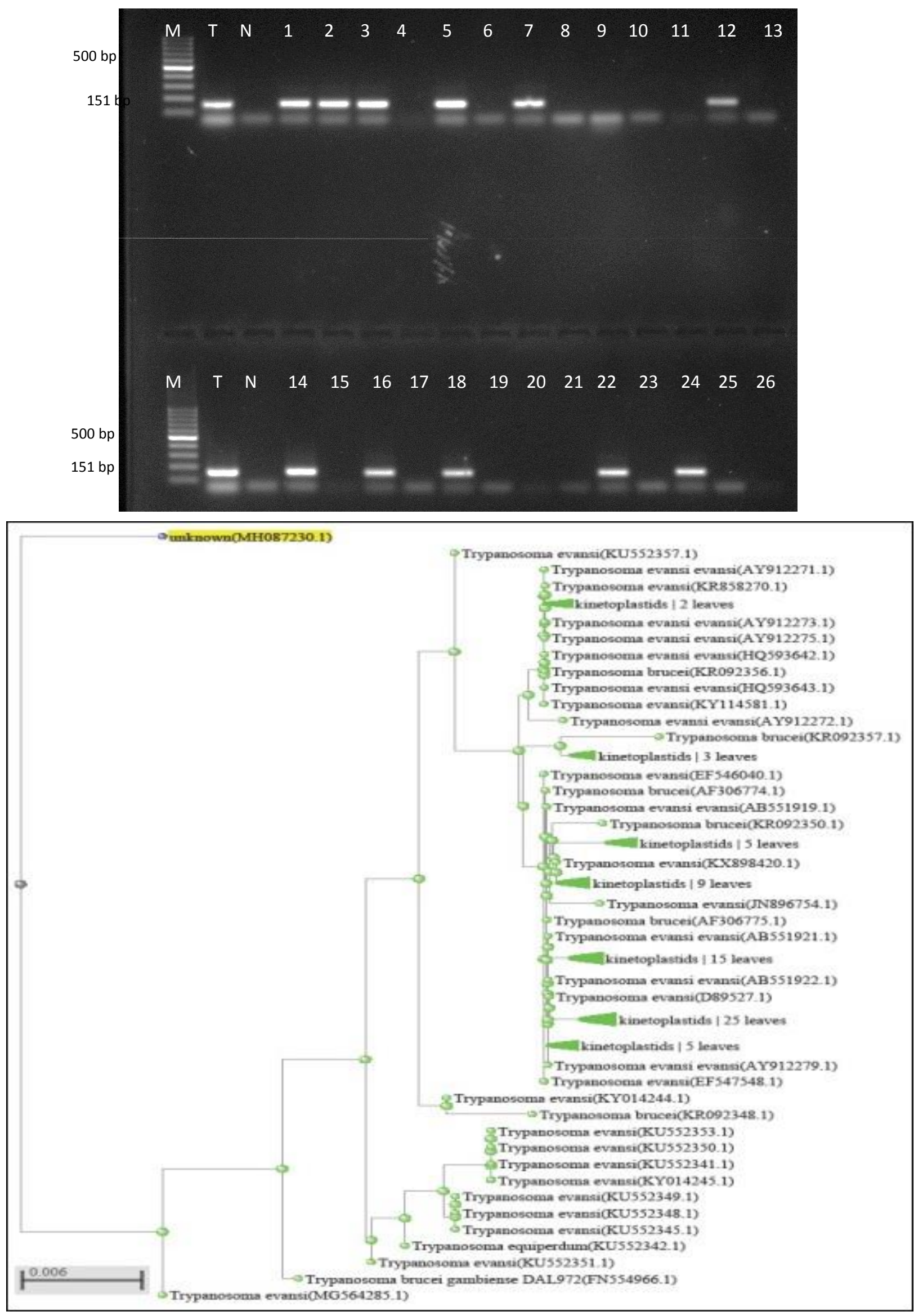